\title{
PRACTICING COMMUNICATIVE LANGUAGE TEACHING APPROACH OF ENGLISH GRAMMAR TEACHING: TEACHERS' PERSPECTIVES IN CHINA COLLEGES
}

(iD) Zhou Tianli ${ }^{1}$
(i) Nor Shahila
Mansor ${ }^{2+}$
(D) Lay Hoon Ang's
(i) Sharon Sharmini

Article History

Received: 4 June 2021 Revised: 6 July 2021 Accepted: 12 August 2021 Published: 9 September 2021

\section{Keywords}

China English teachers Communicative language English grammar teaching Rationales

Suggestions

Teaching

Teaching effects.

\author{
${ }^{\prime}$ Department of Foreign Languages, Faculty of Modern Languages and \\ Communication, Universiti Putra Malaysia, Serdang, Selangor, Malaysia; \\ International Education School, Tongren Polytechnic College, Guizhou, \\ China. \\ 'Email: zhoutianli45@gmail.com Tel: 8618569099256 \\ ${ }^{2,3}$ Department of Foreign Languages, Faculty of Modern Languages and \\ Communication, Universiti Putra Malaysia, Serdang, Selangor, Malaysia. \\ ${ }^{2}$ Email:nsm@upm.edu.my Tel: 60129300229 \\ ${ }^{s}$ Email: hlang@upm.edu.my Tel: 60389468928 \\ ${ }^{4}$ Department of English, Faculty of Modern Languages and Communication, \\ Universiti. Putra Malaysia, Serdang, Selangor, Malaysia. \\ ${ }^{4}$ Email:s_sharmini@upm.edu.my Tel:60123977734
}

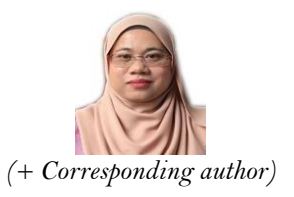

check for
updates

\section{ABSTRACT}

The communicative language teaching (CLT) approach has been extensively used in English teaching in recent decades. Many scholars have investigated CLT and English teaching from various perspectives, but few have examined teachers' attitudes towards the CLT approach and its usage in English grammar teaching. This study aimed to investigate the rationale, the teaching effects and suggestions of English teachers in using CLT in English grammar teaching in China colleges. A qualitative research method was adopted and data was collected through an open-response questionnaire from 13 English teachers of 6 universities in China. The analysis of the data collected revealed that most of the China English teachers used CLT. Their rationale for using it are summarized in this study. The results show that CLT positively affects China college students' English grammar learning despite some limitations, especially in cultivating their communicative competence, motivating their study interests, and modifying the classroom atmosphere, which also helps build students' confidence. Moreover, most of the participants recommended using CLT to conduct English grammar teaching, and eight suggestions were presented to help English teachers conduct the CLT approach to grammar teaching. This study could prove a good reference for teachers who would like to teach English grammar under the CLT approach and enhance their understanding of CLT.

Contribution/ Originality: This study is one of very few studies which have investigated the China English teachers' attitudes towards English grammar teaching under the CLT approach, which enhances our understanding of CLT in different circumstances and provides references for those teachers who intend to teach English grammar under the CLT approach.

\section{INTRODUCTION}

Native speakers rarely think about the language rules, but in a country where English is the second language, most teachers believe that grammar is essential (Fitriyani, Warni, \& Kaniadewi, 2020). If you don't know the basic rules of English, you may not express yourself accurately and may be misunderstood by others. Grammar teaching 
has always troubled English teachers globally. Many of them focus primarily on points, concepts, and rules of grammar in their classes, which leads their students to passively learn the English grammar (Luo, 2019). Most language learning classrooms around the world use the traditional teaching methods, such as present-practiceproduce, but the effect of this kind of teaching is not prominent. Xie (2019) argues that many students learn English grammar by memorizing its rules, instead of internalizing its implicit knowledge, and therefore they often make mistakes in its application.

In recent years, numerous researchers are trying to find useful way and innovations to teach English grammar as well as to ensure continuity of education (Moron \& Mujtaba, 2018; Nor, Hazlina, \& Normaliza, 2017). Widodo (2006) proposed a five-step grammar teaching approach, combining the notions of "practice and consciousnessraising, explicit and implicit knowledge, and deductive and inductive approaches" (p. 122). Zheng (2015) paid attention to explicit and implicit grammar teaching, and discussed and analyzed two kinds of grammar teaching strategies and their advantages in grammar instruction. Another group of researchers argued that the respondents preferred grammar to be specifically taught in ESL classrooms; nevertheless, they regarded implicit instruction as appropriate when meeting the needs of students. Besides, the educators should adjust their teaching strategies according to their teaching experience (Rahman \& Rashid, 2017).

Studies on grammar teaching have promoted grammar teaching skills to some extent. However, they have mainly focused foremost on teaching students how to write sentences with the right structures, but students fail to use them with flexibility in their daily life. Ellis (2006) pointed out that it is ideal to use methods of measuring acquisition that tap into learners' ability to use grammatical structures they have been taught in communication. Consequently, some researchers also suggested that grammar teaching should be combined with the communicative language teaching (CLT) approach to improve students' linguistic competence as well as their communicative competence and use them flexibly in our grammar teaching work (Zhong-Guo \& Min-yan, 2007). Luo (2019) applied CLT for empirical research on grammar teaching for English majors at secondary vocational schools, which further examined the positive influence of CLT on grammar teaching.

Previous studies on CLT and English grammar teaching generalize the advantages of CLT in English teaching and guide how to conduct English teaching by using CLT. However, few studies provide robust empirical evidence on grammar teaching experiences to check whether the CLT approach should be applied in every English grammar teaching class and whether it suits grammar teaching practices in different countries. English grammar is an integral part of English teaching in China colleges, because it is a testing point in College English Test (CET) 4 and 6, which is a compulsory English test of China college students to meet their graduation requirement. Therefore, referring to the research gap between the current study and previous studies, it was essential to examine such China English teachers that have experience applying the CLT approach in the process of grammar teaching. This study aimed to find out the rationale, the teaching effects, and the teaching suggestions of using CLT in English grammar teaching in the context of English class in China colleges.

More specifically, the study attempted to address three research questions: (1) Why do China English teachers use CLT in grammar teaching? (2) What are the teaching effects of CLT on learners' understanding and use of the English grammar? (3) Do the China English teachers recommend using CLT in English grammar teaching and what are their suggestions?

\subsection{Theoretical Framework}

The communicative language teaching approach was applied and examined throughout the whole study. Smith (1960) in his book Teaching Language as Communication developed a rational approach to the teaching of language. In 1970s, Dell Hymes had first put forward the notion of "communicative competence", which emphasized upon form, content, and structured teaching, contrary to structuralism, and ignored competency development. He believed that people pursuing language studies in the real world were not “identical speech groups" or "ideal 
speaker-listeners", but people with such language abilities that exist in complex speech groups (Hymes, 1972). Hymes' communicative competence theory has provided an important theoretical basis for applied linguistics and language teaching practice.

Ten years after Hymes' communicative competence theory was proposed, two linguists from Canada, Canal and Swain further supplemented the theory. Their views belonged to the category of applied linguistics, with a more specific explanation and guidance of foreign language teaching and second language acquisition (Canale \& Swain, 1980). The expanded doctrine of communicative competence was refined into four different subcompetencies by Canale and Swain (1980), one of which is grammatical ability to create grammatically correct utterances. They argued that without some knowledge of grammar, meaningful or verbal communication is impossible. Ellis (Ellis, 1996) proposed that "the instrumental aim of a communicative approach was to produce students who can communicate both orally and in writing with native speakers in a way appropriate to their mutual needs" Ellis (1996) also believed that even though grammar played a significant role in language teaching, it would lose its meaning without the social context, so Ellis argued the communicative approach must be "culturally attuned and culturally accepted". Besides, the main principle of communicative competence revolutionized language teaching by redefining its goals and the strategies to achieve them. It also helped to explain why so many learners experienced low levels of communicative capacity in structure-based approaches. Similarly, Luke and Dooley (2011) asserted that the framework of grammatical fields, along with tenor and mode, enables teachers and students to focus on what texts say. It helps them understand how words, grammar and discourse, give shape to events and attempt to establish relations of power between authors and readers, speakers and listeners. However, Dai (2020) proposed that English learners have acquired certain grammatical skills of English, but they lack precisely the discourse ability, the sociolinguistic ability and the contextual adaptability, or a comprehensive use of these abilities. It was also pointed out that the teaching of English at university level in China was no longer focused on the teaching of basic grammar rules, but rather on the transition to the development of comprehensive English application skills (Dai, 2020).

To conclude this discussion, previous studies have although emphasized the importance of communicative competence in language learning, but they did not neglect the significant role of grammar in the process of cultivating the language using abilities, and vice versa. The CLT approach should not only enhance students' communicative ability in using English but also cultivate their ability to acquire English grammar more easily and in a better way. If done accurately, the applicable rules that needs to be observed in language communication will slowly become an internal factor for second language learners to complete the transition or conversion from acquiring language ability to showing communicative ability.

Therefore, the present study argued that the teaching of grammar and the development of students' communicative competence are mutually reinforcing, and the conduct of communicative language teaching approach should be adjusted in different social contexts. To examine this phenomenon, the present study aimed to focus on measuring China English teacher's views towards the CLT approach as well for grammar teaching in English classrooms. The study would also explore the rationale, the teaching effects and suggestions for a successful use of CLT at China colleges.

\section{LITERATURE REVIEW}

\subsection{Communicative Language Teaching (CLT)}

Communicative language teaching (CLT) is an approach to the teaching of second and foreign languages that focuses on meaningful communication in real life as a means and the goal of learning a language (Baydikova \& Davidenko, 2019). CLT originated in Europe during the 1970s when the revolution of British language teaching took place and linguists began to focus on communicative competence rather than on grammatical competence which paid much attention to the mastery of structures. In addition to Hymes (1972), who first put forward the 
phrase "communicative competence", Wilkins (1972) too made a great contribution to the formation and development of CLT because he proposed the functional or communicative definition of language. Wilkins (1972) sought to explain the meanings behind the communicative uses of language, which are national categories and categories of communicative function. His book, National Syllabuses, had a great impact on communicative language teaching, which has wildly expanded in Britain and American since the mid-1970s.

Canale and Swain (1980) identified four dimensions of communicative competence, which included grammatical competence, discourse competence, social-linguistic competence, and strategic competence. Richards (2006) refined and interpreted communicative competence, including the language knowledge of knowing (1) how to use language for different purposes and functions; (2) how to vary our use of language according to different occasions and participants; (3) how to produce and understand different types of texts; (4) how to maintain communication despite having limitations in one's language knowledge. Thus, it could be generalized that communicative competence is for students to use language accurately and appropriately and to produce meaningful communication. Richards (2006) also proposed some principles for communicative language teaching approaches, including making real communication the focus, and providing opportunities to experiment and develop both accuracy and fluency are emphasized.

\subsection{CLT in Grammar Teaching}

Although the development of a teaching approach transferred the focus from grammatical competence of the traditional teaching approach to communicative competence, it doesn't mean that grammar teaching is not important or should be neglected during language teaching. According to Brumfit (2000), grammar is the basis of a language and learners cannot use English if they don't know how to put them together, even if they know a million English words. Moreover, Ellis (2006) has proved that learners with instruction generally had a better performance of grammatical competence and proficiency and progressed faster than naturalistic learners, though grammatical competence can be achieved through naturalistic learning. Ellis (2006) identifies grammar teaching as it "involves any instructional technique that draws learners' attention to some specific grammatical form in such a way that it helps them either to understand it meta-linguistically and process it in comprehension or production so that they can internalize it”.

Many studies have proved the advantages of CLT in grammar teaching. Kong (2016) did a comparative study of CLT and grammar-translation approaches in junior middle school. The results showed that CLT was more efficient than the traditional grammar teaching approach because it changed the role of teachers, helped students pay attention to the grammar form and structures as well as the grammar meaning and functions, and made the class more active. Klimova, Klimova, and Dubinka (2019) and his team studied how to improve students' communicative ability in business English, and they found CLT as the main teaching method that could help learners apply vocabulary and grammar structures accurately and spontaneously in speech. Baydikova and Davidenko (2019) tried to propose some specific principles for teaching communicative grammar and his study focused on the pre-communicative activities and communicative activities in class. This study concluded that CLT was a method to improve EFL learners' competence to interact in different contexts which simulated real-life interaction, motivated students' communication, and implied language for meaningful uses (Baydikova \& Davidenko, 2019).

On the contrary, some scholars also discovered the negative impact of CLT in grammar teaching. Ahmed (2013) pointed out some problems for teachers applying CLT for the secondary level of education in Bangladesh. Firstly, teachers did not realize the learner-centered principle, so the class remained teacher-oriented. Secondly, the nature management of CLT was not achieved. Moreover, there was a lack of variation in teaching and the technique of grammar in CLT remained like that of grammar-translation method (GTM), which affected the communicative compacity of language learners (Luke \& Dooley, 2011). Besides, there was also a lack of relation of grammar with 
realia, which meant grammar teaching was rarely related to real situations (Ellis, 1996). Kong (2016) also summarized the disadvantages of CLT after she generalized its advantages. According to Kong (2016), there were no clear standards for teachers to design good communicative activities, which may harm the feasibility. Second, teachers sometimes paid less attention to the instruction of grammar, and instead only focused on creating activities. Moreover, the activities did not take into account the students' language ability and lack of guidance.

Through reviewing the relative literature, advantages and disadvantages of CLT methods have been studied by many researchers. Nevertheless, the application of these approaches in China college English classes is rarely examined. Very few scholars have paid attention to teachers' beliefs about applying CLT in grammar teaching process. As Dai (2020) mentioned, this is the time for Chinese English teachers to adjust their English teaching methods. To address this gap, this study examined China teachers' attitudes towards CLT and investigated, from the teachers' perspectives, the rationale, the grammar teaching effects, and suggestions put forward by them to help teachers gain a better understanding of conducting CLT in non-English speaking countries.

\section{METHODS}

This study aimed to investigate the rationale, the grammar teaching effects, and suggestions based on the China teachers' experience and attitudes of the application of the CLT approach in English grammar teaching. Hence a qualitative descriptive approach was adopted because qualitative research method is to figure out what is going on under a certain context (Croker, 2009). An open-response questionnaire was created as the data collection method for this research. Unlike a closed-response questionnaire in a quantitative study, an open response tool requires participants to answer in their own words followed by a qualitative analysis of the collected data. The qualitative descriptive analysis includes creating categories based on responses, utilizing the NVivo software to recognize the high-frequency words for coding and finally labelling the categories with the high-frequency words (Brown, 2009).

\subsection{Participants}

To meet the requirement of the research questions and research purposes, English teachers from 6 universities in China were invited to serve as participants of the study. After preliminary communication, 13 university English teachers finally agreed to participate in this study. The 13 participants included 10 female and 3 male teachers, and each had university teacher qualification certificates. The education degree of 11 English teachers was Master's, and the other 2 were bachelors in English. Besides, each held rich English teaching experience, the shortest English teaching career was 3 years and the longest was 16 years. Before participating in this study, the researchers had communicated with the participants by telephone to explain the purpose and the application of the study. The confidentiality of the participants' identity and personal information was promised and also to share the research result with them after completion. To minimize bias in the analysis and comments, the study was subjected to 'member checking' and was shared with the participants to check whether the article contradicted the original meaning expressed by them.

\subsection{Design of Open-response Questionnaire}

Considering the complexity and difficulty of data analysis of the open questionnaire, the questionnaire was designed according to the corresponding research questions, and was not excessively lengthy (Brown, 2009). The writing of the question items followed 12 guidelines to write good open response questionnaires recommended by Brown (2009). Doing so ensured that the questions were clearer and more concise. The questionnaire was bilingual (Chinese \& English), so that the participants could better understand the questions according to their personal language habits. Second, attention was given to the format of the questionnaire. When setting the questionnaire format, researchers distributed the questionnaire into three parts: general instructions, personal information, and 
the body (Korb (2012). The first part of general instructions included the researcher's introduction, purpose of the research, confidentiality statement, voluntary participation, and how to submit the questionnaire. It was followed by questions on demographics viz., gender, age, and other relative information about the respondents. Furthermore, in the body of the questionnaire, the researchers inserted general directions for guiding the respondents how to answer the questions. Before the formal investigation, a feasibility and comprehensibility study was done with $2-3$ participants to check if the questions were reasonable and comprehensible. The language and the format of the questions were adjusted based on suggestions received from these respondents.

\subsection{Data Collection and Analysis}

During the stages of data collection and analysis, the well-designed open-response questionnaire (see Appendix) was released to the participants through www.wjx.cn, the Chinese online questionnaire survey platform. When all participants had finished the survey, the researchers downloaded the survey results in MS-Excel and transcribed the data in English language for analysis. In addition, the results were converted into a word document in order to create categories. The researchers browsed the original response sheets carefully and repeatedly. NVivo was used to recognize the high-frequency words to code and set categories. Furthermore, the categories were labeled using the high-frequency words with the researchers' screening, which depended on the examiner's items (Brown, 2009). Finally, after the study patterns had been discovered, the last step was to present the data as responses to each research question and conduct an analysis and discussion.

\section{FINDINGS AND DISCUSSION}

\subsection{Rationales of China English Teachers Using CLT on Grammar Teaching}

To respond to research question 1, the researchers designed the first part of the questionnaire which included, besides the personal information of the participants, the reasons why teachers had chosen CLT for grammar teaching. The summary of responses is illustrated in Table 1 :

Table-1. China English teachers' use of CLT in grammar teaching.

\begin{tabular}{c|c|c|c|c}
\hline Teachers & Gender & Length of English teaching & Know CLT well or not & Used CLT or not \\
\hline $\mathrm{T} 1$ & $\mathrm{~F}$ & $5 \mathrm{Ys}$ & $\mathrm{Y}$ & $\mathrm{Y}$ \\
\hline $\mathrm{T} 2$ & $\mathrm{~F}$ & $7 \mathrm{Ys}$ & $\mathrm{Y}$ & $\mathrm{Y}$ \\
\hline $\mathrm{T} 3$ & $\mathrm{~F}$ & $10 \mathrm{Ys}$ & $\mathrm{Y}$ & $\mathrm{Y}$ \\
\hline $\mathrm{T} 4$ & $\mathrm{M}$ & $16 \mathrm{Ys}$ & $\mathrm{Y}$ & $\mathrm{Y}$ \\
\hline $\mathrm{T} 5$ & $\mathrm{M}$ & $7 \mathrm{Ys}$ & $\mathrm{Y}$ & $\mathrm{Y}$ \\
\hline $\mathrm{T} 6$ & $\mathrm{~F}$ & $8 \mathrm{Ys}$ & $\mathrm{YW}$ & $\mathrm{Y}$ \\
\hline $\mathrm{T} 7$ & $\mathrm{~F}$ & $3 \mathrm{Ys}$ & $\mathrm{NW}$ & $\mathrm{Y}$ \\
\hline $\mathrm{T} 8$ & $\mathrm{~F}$ & $8 \mathrm{Ys}$ & $\mathrm{NW}$ & $\mathrm{Y}$ \\
\hline $\mathrm{T} 9$ & $\mathrm{~F}$ & $11 \mathrm{Ys}$ & $\mathrm{Y}$ & $\mathrm{Y}$ \\
\hline $\mathrm{T} 10$ & $\mathrm{~F}$ & $6 \mathrm{Ys}$ & $\mathrm{Y}$ & $\mathrm{Y}$ \\
\hline $\mathrm{T} 11$ & $\mathrm{M}$ & $7 \mathrm{Ys}$ & $\mathrm{Y}$ & $\mathrm{Y}$ \\
\hline $\mathrm{T} 12$ & $\mathrm{~F}$ & $15 \mathrm{Ys}$ & & \\
\hline $\mathrm{T} 13$ & $\mathrm{~F}$ & $8 \mathrm{Ys}$ & $\mathrm{NW}=\mathrm{Not}+\mathrm{ll}$
\end{tabular}

Note: $\mathrm{F}=$ Female, $\mathrm{M}=$ Male, $\mathrm{Ys}=$ Years, $\mathrm{Y}=$ Yes, $\mathrm{N}=\mathrm{No}$, NW=Not well.

A total of 13 questionnaires were distributed and all of them were collected. T3 had not previously used CLT in grammar teaching, so she quit the survey after finishing the survey question 4 . The remaining 12 questionnaire survey forms were analyzed in this study. The teaching years of English teachers ranged from 3 to 16 years. According to the data, 9 English teachers knew about CLT well, and 4 teachers did not know much about CLT;12 teachers had used CLT for English grammar teaching except for T3, so it was evident that most English teachers were familiar with CLT and used CLT in grammar teaching. 
To explore why English teacher used CLT in English grammar teaching, the researchers further categorized the responses of teachers as were given to Question No 5 of the survey (see Table 2).

Table-2. Rationale of China English Teacher Teaching Grammar under CLT Approach.

\begin{tabular}{|c|c|c|}
\hline Rationales & Teachers & Total No. \\
\hline 1. Just tried because it is a popular teaching method. & $\mathrm{T} 1$ & 1 \\
\hline $\begin{array}{l}\text { 2. To increase interaction with the students and activate the classroom } \\
\text { atmosphere. }\end{array}$ & T8 & 1 \\
\hline 3. To improve the students' accuracy of language use. & T5 T12 & 2 \\
\hline 4. To promote students' English communicative competence. & $\mathrm{T} 7 \mathrm{~T} 10$ & 2 \\
\hline 5. To cultivate students' ability of language use. & $\mathrm{T} 2 \mathrm{~T} 4 \mathrm{~T} 6$ & 3 \\
\hline 6. To encourage students to speak English in a real situation. & T6 T8 T11 T13 & 4 \\
\hline
\end{tabular}

As seen in Table 2, six items illustrated why English teachers used CLT to conduct English grammar teaching. T1's rationale for applying CLT in teaching grammar was because it was a popular teaching method, while T8 considered that the CLT approach could increase the interaction between the teacher and the students and to activate the classroom atmosphere. T5 and T12 intended to improve the students' accuracy of the language use by introducing CLT in grammar teaching; T7 and T10 mentioned using CLT in grammar teaching to promote the students' English communicative competence. English teachers, T2, T4, and T6, admitted that most of their students lacked the ability of language use because of the traditional grammar teaching method, which overemphasized memorizing the grammar rules and that the grammar teaching was mostly teacher-centered. However, CLT changed grammar teaching into student-centered and offered more opportunities for students to cultivate their ability of language use. T11 and T13 shared that the main reason for using CLT was that it encouraged students to speak English in a real situation, which was pointed out by T6 and T8 as well. Finally, T13 mentioned that "Communication is the most important purpose of language use, while the purpose of language learning is to be able to use it in real communication situations. The way of language learning also lies in communication practice.”

Based on the reasons given by respondents, it was revealed that most teachers applied the CLT in grammar teaching because they were not satisfied by the teaching effects of grammar-translation method (GTM). The respondents agreed that they intended to cultivate the students' communicative competence of using language in a real communicative context, which is emphasized by Dell Hymes (1972), Canale and Swain (1980) and many other scholars. Many previous studies have analyzed the advantages and disadvantages of GTM. Mart (2013) asserted that GTM increased the chance of interaction in class and that it enriched learners' vocabulary and helped them achieve better language proficiency. Aqel (2013) also pointed out that GTM was one of the most effective methods as it showed how to use English grammar rules accurately through translating.

However, a few scholars expressed the negative effects of GTM highlighting that it only focused on grammar rules rather than other acquisition of language skills, specially oral or communicative competence. Liu and Shi (2007), for instance, argued that GTM paid little attention to learners' speaking or listening, and it is a teachercentered model that would frustrate students because of the endless memorization of grammar rules. Besides, GTM was based on the teacher's lecture, and ignored the differences in students' learning abilities, language talents, and educational backgrounds. The traditional grammar teaching further made the classroom atmosphere more stilted, with little student participation, which seriously affected the effectiveness of teaching (Cao, 2020). Nevertheless, GTM seems still widely applied today, because it is very easy for teachers to use, as many teachers lack practice and are afraid to try new pedagogies. As mentioned by Ahmed (2013), the lack of a good grasp over new pedagogies also affects grammar teaching practices. The reasons given by the present study's participants are indicative of the communicative approach to teaching English grammar in the China college English classroom, because according to the view of Ellis (1996) the communicative approach should be made suitable for Asian conditions, thus, English 
teachers in China should not blindly apply communicative pedagogy guidelines, the specific teaching practices need to be implemented according to the students' learning circumstances and standards set in the school curriculum.

\subsection{Teaching Effects of English Grammar Teaching under the CLT Approach}

In response to research question 2, data was collected from the Second Part of the questionnaire survey. The survey question 6 dealt with the impact of CLT (Figure 1) and revealed the views of respondents. For instance, 8 teachers held the view that the CLT approach made a positive impact on grammar teaching, 3 teachers believed that CLT would have both positive and negative impact on grammar teaching, while only 1 teacher considered CLT as not an ideal teaching method of grammar teaching.

\section{Impact of CLT on Grammar Teaching}

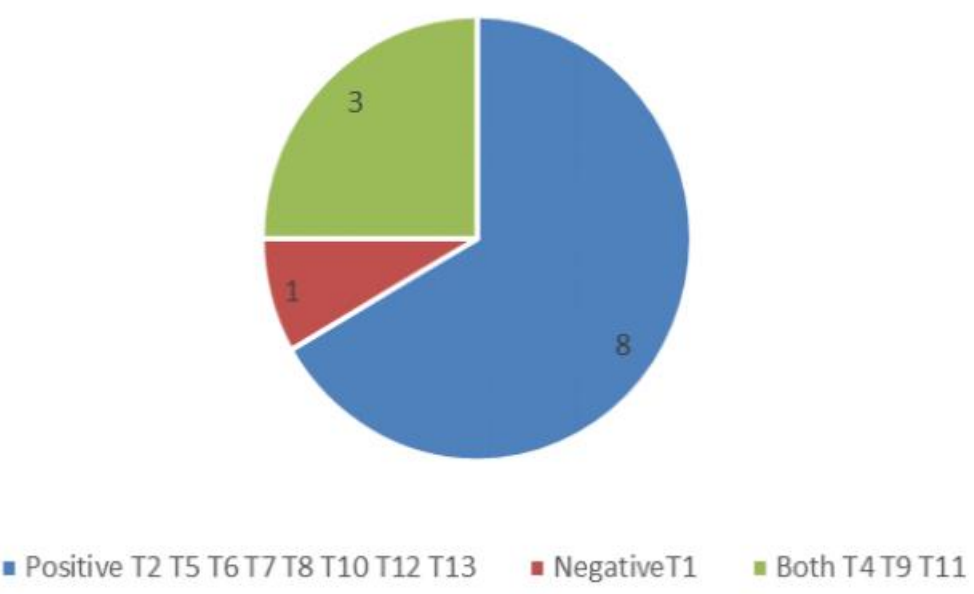

Figure-1. Impact of CLT on grammar teaching in the view of teachers.

The survey question 7 further explained their opinions. The eight teachers who considered that CLT made a positive impact on grammar teaching ( T2, T5, T6, T7, T8, T10, T12, and T13) formed the majority of teachers. T2 exclaimed that "By using CLT in grammar teaching, language teaching changes into language acquisition." Besides, she also pointed out that students became more accurate in using English grammar and expression, which was also supported by T5. Secondly, T10 mentioned that CLT made students' grammar more flexible and fluent, which enhanced their confidence in speaking English. Hence, it greatly developed their interest in English learning, was opined by T13.

Another positive point proposed by T6, T8, and T12 was that communicative competence is enhanced by learning and using English grammar in a real situation. T6 claimed that "The communicative language teaching method improved students' adaptability in the process of actual communication." T8 argued that "CLT helped the students to correctly understand the meaning of language, made them in the state of communication, realized their communicative ability.”. In addition, T12 said communicative language teaching was not only oral teaching, but also included reading, writing, listening, and speaking under the guidance of teachers. The development of skills like listening, speaking, reading, writing, and other specific behaviors improved their foreign language knowledge and communication ability. One more positive effect of CLT was mentioned by T7 that CLT was a good language teaching method because it not only inspired student's activity in learning, but also activated the classroom atmosphere, which made the classroom sometimes full of laughter for some interesting performances.

On the other hand, some negative factors were also pointed out by T1, T4, T9, T11. T1 was the only respondent who did not agree with the positive impact of CLT; instead, she argued that students could not adapt very well, and sometimes it was difficult to activate them, so CLT approach might not be applied well in grammar 
teaching. T4 also remarked, "Although CLT has many advantages, it is still not perfect because it is difficult to guarantee the systematization of grammar item arrangement when organizing syllabus with function and idea as clues." Similarly, T9, considered it was not suitable for lower-level English classes to adopt CLT in grammar teaching, though there were benefits for higher level English classes. One more negative point was added by T11, who doubted that if the classroom gets too activated by CLT, it may be out of control and would cost teachers much more energy in managing the order of the classroom.

This question actually focused whether CLT was a meaningful and fluent communication method and served as an ideal teaching method to help learners acquire accurate grammar structures and learn how to use it appropriately. From the China college English teacher's answer, theoretically, the answer should be positive, because CLT balances fluency and accuracy and regards both as important in real communication, which is agree with the view of the scholars who have stated the advantages in previous literature (Klimova et al., 2019), except those teachers need to follow the principle to be tolerant of learners' grammatical errors and leave them uncorrected during language production. Interestingly, it is believed that CLT should be considered efficient if the class and activities are properly designed, and techniques are well applied. Baydikova and Davidenko (2019) points out that CLT has advantages when lecturers follow some specific principles: First, the teaching material should be relevant to its communicative function and situation; second, students should be involved in real-life contexts with meaningful communication. It can also be inferred from their study that pre-communicative activities are quite important to lay a foundation for students' accurate and fluent language production in communicative activities, such as matching, blank filing, sentence constructing, etc.

\subsection{Teachers' Suggestions on Practicing CLT in English Grammar Teaching}

In response to the research question 3, the researchers had designed survey questions Nos. 8 and 9. To the survey question 8, most of the teachers recommended using CLT in grammar teaching, except T7, who was not sure whether to recommend it or not. The reason given by T7 was, "I believe the communicative language teaching approach is suitable for public English teaching and is worth popularizing; however, it is not suitable for all English-related subjects or situations, educators should use it flexibly according to the differences of learning objects.”

The rest of the teachers recommend using the CLT approach in grammar teaching, even though T1, who held a negative opinion about the impact of CLT in the previous question, also recommended that English teachers should try CLT according to students' actual English level and situation. Suggestions for applying CLT in English grammar teaching are summarized in Table 3.

Table-3. Teachers' Suggestions for Conducting CLT in Grammar Teaching.

\begin{tabular}{l|l|l|}
\hline Teachers & Suggestions & Stages \\
\hline T11 T13 & 1. Familiarize with CLT & Before class \\
\hline T6 & 2. Set study objectives before class & \\
\hline T1 T7 T11 T13 & 3. Design class content based on students' English level \\
\hline T1 T2 T4 T7 T9 & 1. Subjects for practicing should be close to a real-life situation \\
\hline T10 T12 & 2. Focus on communicating and interesting in grammar teaching \\
\hline T5 & $\begin{array}{l}\text { 3. Insert project-based teaching in order to make CLT application } \\
\text { more effective }\end{array}$ \\
\hline T8 T11 & $\begin{array}{l}\text { 4. Pay attention to the teaching time and classroom control during } \\
\text { class }\end{array}$ \\
\hline T11 & 1. Reflect on your teaching after the class \\
\hline
\end{tabular}

After categorizing and summarizing, 8 suggestions given by the participants were found (Table 3 ). They were further categorized into three stages in the process of grammar teaching namely before class, during class, and after class. During the stage of before class, a teacher should be familiar with the CLT (T11\& T13), set study objectives 
(T6), and design class content based on students' English level (T1, T7, T11 \& 13 ). The teaching content also needs to match the students' actual English level, which is very critical for designing CLT class and was emphasized by four participant teachers.

During the stage of 'during class', 4 crucial points were proposed by teachers. First, the subjects should closely relate to people's real-life situations ( $\mathrm{T} 1, \mathrm{~T} 2, \mathrm{~T} 4, \mathrm{~T} 7$ \& $\mathrm{T} 9$ ). $\mathrm{T} 7$ argued, "teachers should try to ensure the inclusiveness of grammar teaching content. Language is the product of social culture, so it is not immutable. Grammar teaching should not adhere to stereotypes and ignore social reality.” T9 explained it with an example: "While teaching tenses, if the class is ongoing in the afternoon, the teacher can ask students 'What did you eat for lunch today? What will you eat for dinner tonight?'. Such types of sentences meet the Chinese culture of starting a conversation just like some countries people like to talk about the weather when they start a talk."

Second, T10 and T12 suggested that, in the CLT classroom, teachers should focus on communicating and maintaining interesting grammar teaching. This is because CLT is an approach that is designed to cultivate students' communicative competence and language acquisition together. Therefore, the teachers need to make courses more interesting to encourage students to take part in communication initially. Third, T5 recommended that teachers should insert project-based teaching as a more effective approach in applying CLT in English grammar teaching. According to his explanation, the students should be guided to explore and think gradually by using specific project problems in the target language. They can cooperate in groups to solve problems through project learning. Lastly, T11 pointed out the negative aspect of applying the CLT approach in grammar teaching. According to him, adopting CLT may lead to getting the classroom out of control. Along with T8, he suggested that teachers must pay more attention to the teaching time and classroom control during class and manage the class well.

In the next stage of 'after class', only T11 mentioned that a teacher should reflect on his or her teaching after class and find out what is good and what still needed to improve while implementing the CLT approach in grammar teaching.

All eight suggestions covered the three stages of grammar teaching under the CLT approach. Though, it did not cover all the detailed problems that teachers encountered in the process of grammar teaching, but these findings could guide teachers to pay attention to some key issues in grammar teaching. The three stages of English grammar teaching of before, during, and after the class complemented each other and are indispensable. If a teacher is not familiar with the CLT, it would affect the implementation of the whole teaching plan and the teacher would not achieve the desired teaching effect (Ahamed, 2013). This will undermine the teacher's confidence in teaching and would mislead the students' learning direction. At the same time, the implementation of the communicative approach in grammar classroom must be integrated with the actual classroom, in order to achieve the appropriate teaching objectives.

The teachers should also pay attention to the attitudes and emotions of the students during teaching, as well as classroom management for some problems may emerge if we did not conduct the CLT appropriately (Kong, 2016). In addition, post-lesson reflection has an evaluative effect on teaching and learning, enabling teachers to identify problems that still exist in teaching practices and to adjust or fix them. For example, by enhancing the use of multimedia technology in the classroom, teachers can create a lively English learning environment, stimulate an interaction between students and students, students and teachers, and enhance students' expressive English (Cheng, $2021)$ to achieve the communicative grammar teaching effect of the CLT teaching approach.

\section{CONCLUSION}

This study examined the rationale, teaching effects, and teachers' suggestions by investigating China English teachers' attitudes and experiences on the communicative language teaching (CLT) approach in English grammar teaching. The findings of the present study are threefold. Firstly, most participants used CLT to conduct English 
grammar teaching, and six reasons were summarized to illustrate why China English teachers used CLT to teach English grammar. These reasons included increasing interaction with the students and activate the classroom atmosphere, promoting the students' English communicative competence, encouraging students to speak English in real situations and so on so forth. This reflected the problems that exist in China English grammar teaching to some extent and showed how to motivate them to change the situation.

Secondly, most of the China English teachers put forward that the CLT approach played a positive role in English grammar teaching. Through the application of CLT in grammar classrooms, students became more active in class, and the classroom atmosphere improved. At the same time, students deepened their understanding of grammar in the process of oral expression and communication. Their expressions became smoother and more accurate. Furthermore, it was a good way to cultivate students' communicative competence and build their confidence in English learning. However, shortcomings were also pointed out by some teachers. They were concerned that CLT might not be suitable for some low-level English students, and it would be often difficult for teachers to manage the classroom under the CLT approach. Lastly, eight suggestions were put forward by participants to cover the three-stages of teaching, which included the stages of before class, in class, and after class. These suggestions were very useful for those who wanted to use CLT in English grammar teaching.

This study would enable teachers to understand the rationale of China English teachers who want to adopt CLT in grammar teaching classes. The observations collected about the effect of English grammar teaching under this approach shall also deepen their understanding of the communicative language teaching approach and provide a reference to English teachers who want to practice CLT in English grammar teaching. However, this study faced some limitations. The data collection method was single, and the data only resulted from the views of China English teachers. It only reflected the situations of teachers in China, while students' feelings and attitudes were not recorded. Future researchers could investigate CLT under different situations and from various perspectives.

Funding: This study received no specific financial support.

Competing Interests: The authors declare that they have no competing interests.

Acknowledgement: All authors contributed equally to the conception and design of the study.

\section{REFERENCES}

Ahmed, S. (2013). The current practices of teaching grammar in CLT at secondary school level in Bangladesh: Problems and probable solutions. Theory and Practice in Language Studies, 3(8), 1328-1334. Available at: https://doi.org/10.4304/tpls.3.8.1328-1334.

Aqel, I. M. (2013). The effect of using grammar-translation method on acquiring English as a foreign language. International Journal of Asian Social Science, 3(12), 2469-2476.

Baydikova, N. L., \& Davidenko, Y. S. (2019). Teaching communicative grammar to technical University EFL learners. Paper presented at the IOP Conference Series: Earth and Environmental Science.

Brown, J. D. (2009). Open-response items in questionnaires. In Qualitative research in. applied linguistics (pp. 200-219). Palgrave Macmillan: London.

Brumfit, C. J. (2000). The communicative approach to language teaching. Oxford: Oxford University Press.

Canale, M., \& Swain, M. (1980). Theoretical bases of communicative approaches to second language teaching and testing. Applied Linguistics, 1(1), 1-47. Available at: https://doi.org/10.1093/applin/i.1.1.

Cao, J. (2020). Exploring the application of communicative teaching method in higher vocational English teaching---review on a study on the application of communicative teaching method in teaching English in Higher Education Institutions. Contemporary Educational Sciences, 5(1), 85-97.

Cheng, C. (2021). Analysis of the application of communicative language teaching method in college english teaching. English Square, 2(12), 89-91. 
Ellis, G. (1996). How culturally appropriate is the communicative approach? ELT Journal, 50(3), 213-218. Available at: https://doi.org/10.1093/elt/50.3.213.

Ellis, R. (2006). Current issues in the teaching of grammar: An SLA perspective. TESOL Quarterly, 4O(1), 83-107. Available at: https://doi.org/10.2307/40264512.

Fitriyani, A., Warni, S., \& Kaniadewi, N. (2020). English as a foreign language teachers' beliefs about grammar teaching in classroom. ELLTER Journal, 1(1), 12-24.

Hymes, D. (1972). On communicative competence. Sociolinguistics, 269(293), 269-293.

Klimova, I. I., Klimova, G., \& Dubinka, S. (2019). Students' communicative competence in the context of intercultural business communication. XLinguae, 12(1), 207-218. Available at: https://doi.org/10.18355/xl.2019.12.01.16.

Kong, Q. Y. (2016). A comparative study of communicative and grammar translation methods: Exemplified with the english modal verbs teaching in junior middle schools. Master thesis, Shanxi Normal University, China.

Korb, K. A. (2012). Conducting educational research: Developing the questionnaire format. Retrieved from: http://korbedpsych.com/Ro9bQuestionnaire.html.

Liu, Q.-X., \& Shi, J.-F. (2007). An analysis of language teaching approaches and methods--effectiveness and weakness. Online Submission, 4(1), 69-71.

Luo, R. H. (2019). An experimental research on grammar teaching for english majors at secondary vocational school based on communicative teaching method. Master Thesis, Guangxi Normal University, China.

Mart, C. T. (2013). The grammar-translation method and the use of translation to facilitate learning in ESL classes. Journal of Advances in English Language Teaching, 1(4), 103-105.

Moron, V., \& Mujtaba, B. G. (2018). Helping non-English speakers speak English in the workplace. American Journal of Education and Learning, 3(1), 14-26. Available at: https://doi.org/10.20448/804.3.1.14.26.

Nor, S. M., Hazlina, A. H., \& Normaliza, A. R. (2017). Student's perspectives towards innovation of technology in teaching and learning of language. Indonesian Journal of EFL and Linguistics, 2(2), 121-132.

Rahman, A. M. A., \& Rashid, R. A. (2017). Explicit and implicit grammar instructions in higher learning institutions. English Language Teaching, 10(10), 92-101. Available at: https://doi.org/10.5539/elt.v 10n10p92.

Richards, J. C. (2006). Communicative language teaching today. Singapore: SEAMEO Regional Language Centre.

Smith, D. V. (1960). Teaching language as communication. The English Journal, 49(3), 167-172.

Widodo, H. (2006). Approaches and procedures for teaching grammar. English Teaching, 5(1), 122-141.

Wilkins, D. A. (1972). Linguistics in language teaching. Oxford: Arnold.

Xie, C. X. (2019). An empirical study of the effects of micro lecture teaching on students' acquisition of english subjunctive mood in senior high schools. Master Thesis, Hunan Normal University, China.

Zheng, L. (2015). Explicit grammar and implicit grammar teaching for English major students in university. Sino-US English Teaching, 12(8), 556-560. Available at: https://doi.org/10.17265/1539-8072/2015.08.002.

Zhong-Guo, L., \& Min-yan, S. (2007). The relationship between traditional English grammar teaching and communicative language teaching. Online Submission, 4(1), 62-65.

\section{APPENDIX}

An Open-response Questionnaire Survey Based on CLT in English Grammar Teaching

\section{General Introduction}

The purpose of this study is to investigate the practice of the communicative language teaching (CLT) approach in English grammar teaching. Taking English teachers as the volunteer of this survey, this study measures the rationale, the teaching effect and suggestions of CLT on English grammar teaching from the perspective of teachers and examines their attitude towards CLT and their experience in English grammar teaching. This questionnaire is anonymous and will be used only for research purposes and the private information of the participants will not be disclosed. Thank you very much for your participation! 
Part One

This part relates to participants' personal information and responses to RQ1.

For questions 1, 3, 4, please circle the most appropriate response; for question 2 , please fill in the blank with your actual situation, while for question 5, please answer by typing in the blank box using your own words. (If 'yes' or 'not well', please continue this survey; if 'no', please quit this survey)

1 . What is your gender?

Male Female other

2. How long have you been teaching English?

I have been teaching English for_years.

3. Do you know about the communicative language teaching (CLT) approach?

Yes No Not Well

4. Have you ever used CLT in English grammar class?

Yes No

5. Why do you try CLT in grammar teaching?

Part Two

This Part will collect responses to RQ2.

For question 6, please circle the most appropriate response; For question 7, please answer by typing in the blank box using your own words.

6. Does CLT have a positive or negative impact on English grammar teaching?

Positive Negative Both of them

7. What is the effect of using the CLT approach in grammar teaching?

Part Three

This Part will collect responses to RQ3.

For question 8, please circle the most appropriate response; For question 9, please answer by typing in the blank box using your own words.

8. Do you recommend other English teachers apply CLT in grammar teaching?

Yes No Not Sure

9. Do you have any suggestions on conducting the CLT approach in grammar teaching? Or could you share some of your experiences on applying CLT?

Views and opinions expressed in this article are the views and opinions of the author(s), International Journal of English Language and Literature Studies shall not be responsible or answerable for any loss, damage or liability etc. caused in relation to/arising out of the use of the content. 